\title{
Interpreting ecology and physiology of fossil decapod crustaceans
}

\author{
Rodney M. Feldmann \\ Department of Geology, Kent State University, Kent, Ohio 44242, USA
}

Keywords: Crustacea, Decapoda, Mesozoic, Cenozoic, behavior

\begin{abstract}
Decapods are the most diverse and complex group of crustaceans, adapted for life in all parts of the marine environment, many aquatic habitats, and some terrestrial niches. With this diversity of life styles, a vast range of morphotypes of decapods has evolved, exploiting almost every imaginable variation in morphology of the complex exoskeleton that characterizes them. Many of the morphological variants are a response to exploiting a particular niche in which the organisms live or an adaptation to particular behavioral characteristics. Assessing the significance of morphological variation in the fossil record is challenging because of the taphonomic overprint that results in loss of soft tissue, preservation of partial remains of hard parts, and vastly reduced numbers of preserved individuals as contrasted to the once-living population. The purpose of the present paper is to identify aspects of morphology that may be useful in interpreting the behavioral responses of the organism to its environment, with primary emphasis on morphological features of the exoskeleton that are not expressed on all individuals but that occur at low, and unpredictable, frequencies.
\end{abstract}

\section{Introduction: functional morphology}

When assigning significance to a specific morphological attribute, neontologists are able to study the living organisms, observe their behavior, and interpret the functional significance of that morphological attribute. Because paleontologists can observe behavior only by analogy with living organisms, they rely on deductive reasoning to interpret the fossil record. Thus, by noting the crenulated regions near the antennal base of some lobsters or along the inner surface of the propodus of some extant crabs, and observing the behavioral pattern in living animals of generating a rasping sound by rubbing that surface against the carapace margin (stridulation), it is possible to identify similar structures in some fossil remains and to assign to them a similar function (Feldmann \& Bearlin, 1988). Similarly, the function of grooming appendages, characteristic of many shrimp and other decapods, can be inferred on the basis of modern analogy. Much of the work of paleontologists is characterized by this functional morphological approach.

Form and function of the carapace and appendages has been the subject of voluminous literature. The two most comprehensive works are those of Schäfer (1972) and Manton (1977) and their efforts will not be repeated here. Suffice it that feeding behavior may be deduced from the shape of claws and the nature of their denticles, and life style, including swimming, burrowing, free living, can be interpreted from the shape of the carapace. $\mathrm{Nu}$ merous examples are given within those familiar works. Thus, form reflects behavior.

Some crabs exhibit behavior that permits them to live within other organisms. Perhaps the best known are the Pinnotheridae, tiny crabs which may be endosymbiotic within bivalve, gastropod, and polyplacophoran molluscs, brachiopods, echinoderms, enteropneusts, ascidians, worms, and burrows of worms and other decapods (Ross, 1983). Their presence has been noted since the time of Aristotle (Aristotle, 1862). Several free-living pinnotherids have been described from the fossil record (Schweitzer \& Feldmann, 2001) but there has been only one report of pinnotherids within the host organism (Zullo \& Chivers, 1969). Another endosymbiotic association is typified by modern gall 
crabs, the Haplocarcinidae. Some of these tiny crabs perform a specific behavior to induce corals to form a gall that surrounds and protects the animal (Ross, 1983). Their presence in the fossil record should be assured because they are essentially entombed within coral tissue; despite that, none has been reported from the fossil record. However, there are several reports of tiny, cryptic crabs living within sponge and coral structures that are of note (Collins \& Wierzbowski, 1985; Müller \& Collins, 1991; Beschin et al, 1996, 2001). These crabs often form a very diverse assemblage but are almost completely unknown because they are very small, tend to be preserved in the same fashion as the surrounding coral, and are extremely difficult to detect.

\section{Frequency of occurrence of morphological traits within a species}

A different approach to understanding the relationship between morphology and behavioral adaptations may be taken by assessing the frequency of occurrence of a particular morphological trait within a fossil population. Morphological traits may be expressed in all individuals within a species or may be found in only a subset, depending upon the origin of the trait.

Morphological attributes that are necessary for the functioning of all individuals within a taxon should be discernable on all members of the taxon, if the appropriate region is preserved. Swimming behaviour in nektobenthic crabs, for example, is often facilitated by expansion and flattening of the distal elements of some of the pereiopods and transverse elongation of the carapace (Schäfer, 1972). Similarly, decapods adapted for burrowing, for a purely nektonic life, or for other life styles have been characterized on the basis of morphological attributes. Many of these types of characters not only have functional significance but, because of their ubiquitous presence in the population, are useful in identifying and classifying the organism.

Other characters, associated primarily with ontogeny, may exhibit systematic variation that can be expressed as changes in morphometrics of the organism. Thus, allometric growth may be definable within a collection of fossil decapods. Schweitzer \& Feldmann (2000) recognized allometric growth patterns in the Eocene geryonid, Chaceon peruvianus (d'Orbigny) that helped distinguish it from a contemporaneous portunid in which the proportions of the adult portunids were similar to the proportions of the juvenile geryonid.

Characters that are gender-specific are anticipated to occur with a frequency equal to the gender distribution within the taxon. In decapods, that ratio is quite variable and in the fossil record it may be difficult to discern. Schweitzer Hopkins \& Feldmann (1997) studied a large suite of specimens of Eocene-Oligocene mud shrimp from Washington State (USA) and determined that $65 \%$ of the claws were male and $35 \%$ were female. This study is particularly significant because it demonstrated that two previously named species were, in fact, sexual dimorphs of a single taxon, Callianopsis clallamensis (Withers). In a more recent study of PleistoceneHolocene decapods from Guam, Schweitzer et al. (2002) noted that the ratio of males to females, determined on specimens exhibiting well-preserved pleons, ranged from $50 \%$ to $89 \%$. Some shrimp, notably the Pandaloidea within the Caridea, undergo sexual reversal within their ontogeny. The shrimp typically grow to maturity as males, undergo sexual

\footnotetext{
Fig. 1.1 - dorsal view of extant Callinectes sp. with Balanus epibionts (scale bar equals $10 \mathrm{~mm}$ ); 2 - dorsal view of Lobocarcinus pustulosus Feldmann \& Fordyce, with arrows showing the position of a large, straight serpulid and a small, coiled serpulid worm tube (scale bar equals $10 \mathrm{~mm}$ ); 3 - enlarged view of the concave surface of the counterpart of Trichopeltarion greggi DelI, from the Miocene of New Zealand. Outer cuticular material adheres to the counterpart; where the cuticle is fortuitously broken away, a mould of the interior of a balanid barnacle epibiont is revealed (scale bar equals $5 \mathrm{~mm}$ ); 4 -ventral view of Tumidocarcinus giganteus Glaessner, from the Miocene of New Zealand, showing straight-sided, exceptionally wide male abdomen of a feminised individual (scale bar equals $10 \mathrm{~mm}$ ); 5 - dorsal view of Torynomma australis Feldmann et al., from the Cretaceous of Antarctica, showing a severe bopyrid isopod swelling on the right branchial chamber (scale bar equals $10 \mathrm{~mm}$ ); 6 - scanning electron micrograph of a portion of the cuticle of an extant Cancer sp.x from Mexico, showing exfoliating exocuticle and concomitant loss of an encrusting bryozoan (scale bar equals $1 \mathrm{~mm}$ ); 7-malformed claw of an extant Homarus americanus H Milne Edwards, from Maine, USA (scale bar equals $10 \mathrm{~mm}$ ).
} 

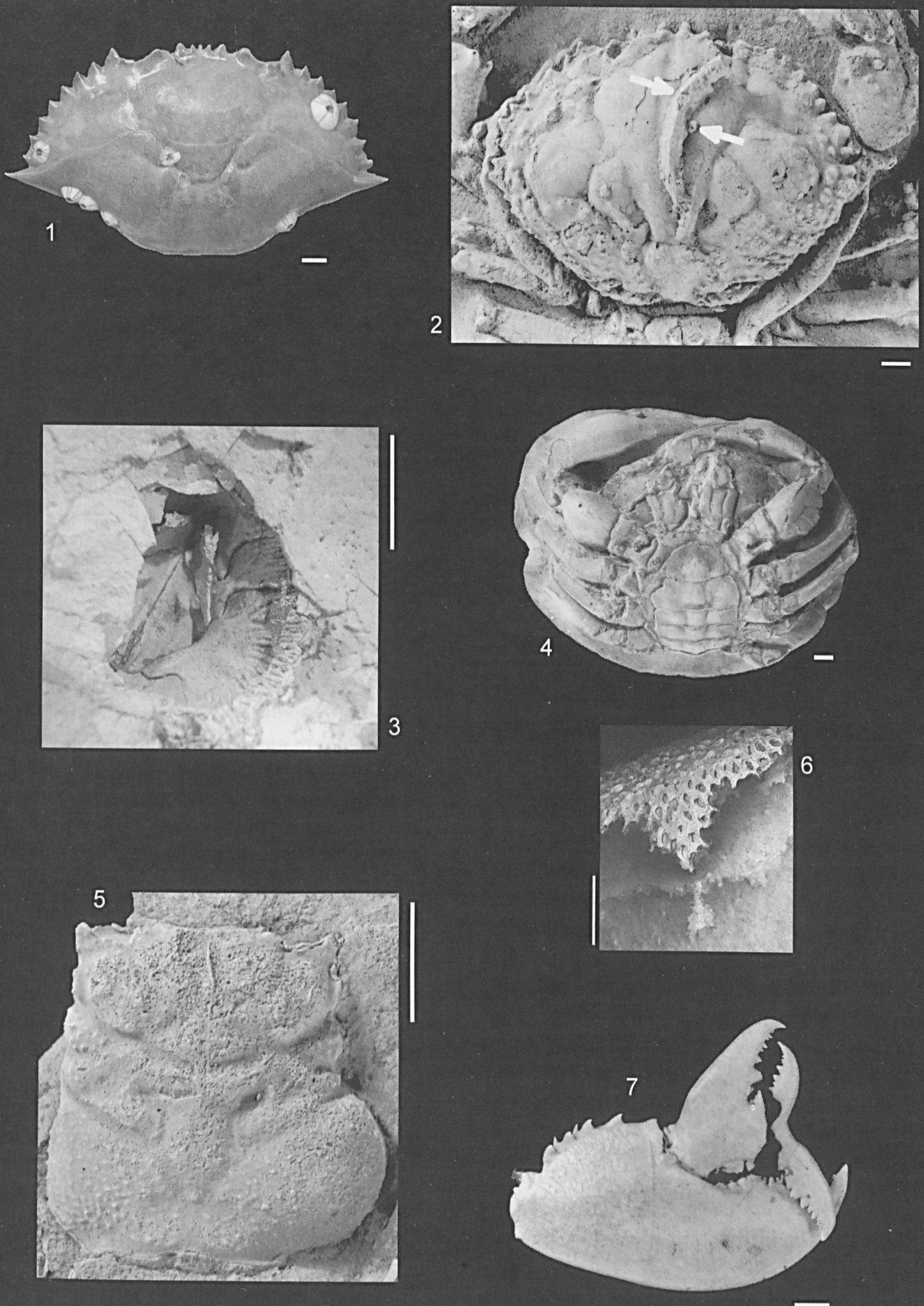
reversal, and live the final part of their lives as females (Bliss, 1982). In this instance, secondary sexual characteristics should be expressed in a 50 / 50 ratio; however, the females should typically be larger than the males. Regardless of the ratio, it is clear that gender differences will result in occurrences of both primary and secondary sexual characteristics at a frequency less than $100 \%$ for each gender.

Finally, certain morphological attributes observable in fossils occur at very low, and unpredictable, frequencies. These characters reflect interaction of the individual crab with its environment. Such conditions as pathology and parasitism, infestation by epibionts, predation, autotomy, and regeneration of normal or abnormal appendages lie within this category. In many cases, these conditions have little effect on the hard parts of the organism and, therefore, are not recognizable in the fossil record. In other cases, such as autotomy or regeneration, the evidence may be quite circumstantial. If an appendage is not preserved in the fossil record, it may be attributed to loss after death of the organism rather than to autotomy. However, some conditions do leave evidences that can be recognized and interpreted, as discussed below.

Most pathological and parasitic conditions in decapods have little effect on the exoskeleton. Two that have been recognized are parasitization within the branchial chamber by bopyrid isopods and within the reproductive system by rhizocephalan barnacles. The former condition has been summarized by Förster (1969), who reported numerous swellings attributed to isopods in the Galatheidae and Prosoponidae of Late Jurassic age and in Cretaceous Ranínídae. Prior to his work, van Straelen (1928) and Houša (1963) had also summarized occurrences of bopyrids. Subsequent to Förster's work, Müller (1984) documented bopyrid swellings in Miocene decapods (Galatheidae, Porcellanidae Bishop (1986) recognized bopyrids in Cretaceous Homolidae, Collins \& Rasmussen (1992) noted their presence in a Late Cretaceous raninid, and Feldmann et al. (1993) recorded them from a Cretaceous species of the Torynommidae (Fig. 1.5). Although this list may not be exhaustive, it is interesting to note that all the fossil occurrences of bopyrids are in galatheids, porcellanids, or in the so-called primitive crabs. Geo- graphically, fossil bopyrids have been identified from as far north as Greenland to as far south as Antarctica. A review of parasitism in extant crustaceans (Overstreet, 1983) noted that bopyrids typically were found in macrurans and anomurans. The only macrurans discussed were shrimp, a group with a poor fossil record.

Other parasites, rhizocephalan barnacles, produce a condition called parasitic castration. The process involves introduction of the barnacle into the intestinal tract and destruction of the androgenic gland in males, and the barnacle ultimately manifests itself by suppressing male hormones and feminizing the males. Females that are infested take on a mature appearance at a prematurely early stage (Overstreet, 1983). This condition has most frequently been observed in portunids, although it is known in other brachyurans as well. The only record of parasitic castration in the fossil record is that of a Miocene xanthid from New Zealand (Feldmann, 1998). Recognition of this condition can be made only by determining that the abdomen of infected males is unusually broadened to simulate the form of the abdomen of females (Fig. 1.4); thus, it is necessary to observe the ventral morphology of a large number of crabs to recognize the condition.

The exoskeleton of decapods provides a firm substratum that may serve as a base for attachment of a host of epibionts on extant taxa (Fig. 1.1), including hydroid and anthozoan cnidarians, bryozoans, bivalves, barnacles, and annelid worms. Almost any organism requiring a firm base of attachment might be anticipated. The incidence of fouling of the decapod carapace by these organisms is quite variable, based upon age of the host, duration of the inter-molt period, location on the organism, ecological setting, and life habit of the host (Ross, 1983). Many of these epizoans have no hard parts and have only a slight chance of being preserved in the fossil record. Others with hard parts may be lost after death of the host as the waxy epicuticle separates from the remainder of the cuticle (Fig. 1.6) (Waugh \& Feldmann, work under way). Still others are not recognized because, when opening concretions, a thin layer of exocuticle may remain attached to the counterpart, obscuring the epibionts (Fig. 1.3) (Waugh \& Feldmann, work under way). The result is that the known occur- 
rence of epibionts on fossil decapods is considerab ly lower than would be anticipated based upon rates of fouling on living decapods. Despite these conditions, a variety of attached epibionts have been recorded (Fig. 1.2), including bryozoans and brachiopods (S.L. Jakobsen, pers. comm.), oysters (Bishop, 1981, 1983; Tshudy \& Feldmann, 1988), barnacles (Glaessner, 1969; Feldmann \& Fordyce, 1996), and serpulid worms (Tshudy \& Feldmann, 1988; Feldmann \& Fordyce, 1996). The most promising possibility for discovering more, and different, epibionts is under study now. Sten L. Jakobsen (Geological Museum, Copenhagen), is using clever, novel preparation techniques to expose a diverse assemblage of organisms from the Middle Danian Fakse Beds in Denmark. This may develop into the most important single locality for studying epibionts, both in terms of prevalence and diversity of occurrence.

Hermit crabs present a quite different combination of host-epibiont interaction because a typical hermit crab occupies the empty shell of a gastropod and a variety of organisms, including hydrozoan cnidarians and bryozoans are known to invest the shell (Taylor, 1994). Specimens from Argentina, currently under study, are typical because the hermit crab initially occupies a relatively small gastropod shell and, instead of replacing the shell with a larger one periodically, the hermit crab relies on the incrusting bryozoans to continue growing and developing a larger, coiled, protective sheath mimicking the form of the original shell. Until very recently, gastropod shells have been taken to be the primary domiciles of choice for hermit crabs, but Fraaije (2003) described an in situ occurrence of a hermit crab within an Early Cretaceous ammonite.

One type of facultative epibiotic relationship that does not seem to manifest itself in the fossil record is that of carrying, or snagging, epibionts as a defensive or camouflaging technique. The sponge crabs, Dromiidae, carry a cap of a sponge, an anemone, or a piece of shell over the carapace that is gripped by the fifth pereiopods. The cap does not adhere to the carapace and, when released by the crab, leaves no trace. Similarly, the spider crabs, Majoidea, typically have setal hairs shaped like the hooks on Velcro@. The hairs trap vegetation and other material as camouflage but, again, leave no trace upon death of the organism.

Epibionts have not been used often by paleontologists to infer aspects of the depositional environment, and their occurrence is all too frequently nested into systematic papers; thus, the information is difficult to extract. Because some of the epibionts may be ecologically sensitive, it is quite possible that we can learn more about the setting in which the decapods lived by studying their intimate associates.

Predation is, of course, a daily occurrence for decapods in modern settings, because they form a food resource for many organisms. However, in the fossil record, evidence of predation is limited, partly because the effects are unrecognized and partly because the effects include total destruction of the remains. Bishop (1975) described a partial crab specimen within a phosphatic nodule and interpreted it to be a regurgitate. A similar interpretation was given for a specimen collected from the Lower Cretaceous of Mexico (Feldmann et al., 1998). Other occurrences have been noted but probably represent hydraulic accumulations. Tshudy et al. (1989) described the feeding habits of nautiloid cephalopods on exuvia of lobsters, noted an instinctive pattern of eating the remains from the posterior of the abdomen towards the anterior, and postulated that this selective ingestion of the abdomen might explain the larger percentage of carapaces than pleons found in the marine fossil record. Interestingly, examination of a large collection of freshwater crayfish from the Pliocene of the western United States showed no difference in the number of carapaces and pleons. Nothing in that environment was utilizing the crayfish skeletons in the fashion of the cephalopods.

Crayfish have been documented as prey species in one instance where it was concluded (Feldmann \& May, 1991) that the systematic removal of the dorsal part of the carapace of Pleistocene crayfish was the result of predation either by a small mammal or by man. Bishop (1972) noted the only occurrence known to me of a crab that was attacked by a toothed animal, presumably a fish, and escaped. Large puncture marks document the unsuccessful interaction - unsuccessful at least in terms of the predator. 
Autotomy, casting off an appendage in the face of predation and regeneration of the lost limb, occurs frequently in the modern world but is difficult to document in the fossil record. Occasionally, a fossil specimen will be illustrated that appears to have an unusually small first pereiopod; however, this is only circumstantial evidence of autotomy. As stated earlier, absence of the appendage on a fossil could arise as a result of many factors. The one unequivocal example of regeneration would be the growth of a deformed appendage as a result of damage during the growth process. The presence of not only deformed, regenerated claws, but also deformed carapaces, has been well documented in living Homarus americanus H. Milne Edwards (Fig. 1.7). I am not aware of any demonstration of the phenomenon in the fossil record, although I have always been curious about the bizarre claw depicted on Schlueteria tetracheles Fritsch \& Kafka (1887, fig. 53).

\section{Summary}

Ecological and physiological characteristics of fossil decapod Crustacea can be inferred by using a variety of functional morphological approaches. Additionally, considering the frequency of occurrence of a morphotype in a population of fossil crabs may reveal features unique to the individual as an indication of its interaction with the environment. Although much is known about the behavioral patterns of living crabs and, by analogy, fossil forms, many significant observations are presented within detailed systematic works and are difficult to locate. This summary is, in part, a notice of the types of interpretations that can be made and a plea to call specific attention to low-frequency, unpredictable morphological characters.

\section{References}

Aristotle. 1862. Aristotle 's History of Animals: in Ten Books, translated by Richard Cresswell. London: Bohn.

Beschin C, Checchi A, Ungaro S. 1996. Crostacei brachiuri dell'Oligocene di Castelgomberto (Lessini Orientali). Studi e Ricerche, Assoc. Amici Mus. civ. 'G. Zannato' 6: 1120.
Beschin C, De Angeli A, Checchi A. 2001. Crostacei decapodi associati a coralli della "Formazione di Cas-telgomberto" (Oligocene) (Vicenza-Italia Settentrionale). Studi e Ricerche, Assoc. Amici Mus. civ. 'G. Zannato' 11: 13-30.

Bishop GA. 1972. Crab bitten by a fish from the upper Cretaceous Pierre Shale of South Dakota. Bull. Geol. Soc. Amer. 83: 3823-3826.

Bishop GA. 1975. Traces of predation. In: Frey RW. (ed.). The study of trace fossils: 261-281. New York: Springer.

Bishop GA. 1981. The lobster Linuparus preserved as an attachment scar on the oyster Exogyra_costata, Ripley Formation (Late Cretaceous), Union County, Mississippi. Mississippi Geol. 2: 2-5.

Bishop GA. 1983. Oyster predation by decapod crustaceans in the Late Cretaceous of the Mississippi Embayment. Georgia Jour. Sci. 41: 24.

Bishop GA. 1986. Occurrence, preservation, and biogeography of the Cretaceous crabs of North America. In: Gore RH, Heck KL. (eds). Crustacean Biogeography: 111-142. Rotterdam: A.A. Balkema.

Bliss DE. 1982. Shrimps, lobsters and crabs. Píscataway, NJ: New Century Publishers Inc.

Collins JSH, Rasmussen HW. 1992. Upper Cretaceous-Lower Tertiary decapod crustaceans from west Greenland. Gronl. geol. Unders. Bull. 162: 1-46.

Collins JSH, Wierzbowski A. 1985. Crabs from the Oxfordian sponge megafacies of Poland. Acta geol. pol. 35: 73-88.

Feldmann RM. 1998 Parasitic castration of the crab, Tumidocarcinus giganteus Glaessner, from the Miocene of New Zealand: coevolution within the Crustacea. Jour. Paleo. 72: 493-498.

Feldmann RM, Bearlin RK. 1988. Linuparus korura n. sp. (Decapoda: Palinura) from the Bortonian (Eocene) of New Zealand. Jour. Paleo. 62: 245-250.

Feldmann RM, Fordyce RE. 1996. A new cancríd crab from new Zealand. N.Z. Jour Geol. Geophys. 39: 509513.

Feldmann RM, May W. 1991. Remarkable crayfish remains (Decapoda: Cambaridae) from Oklahoma - Evidence of predation. Jour. Paleo.. 65: 884-886.

Feldmann RM, Tshudy DM \& Thomson MRA. 1993. Late Cretaceous and Paleocene decapod crustaceans from James Ross Basin, Antarctic Peninsula. Paleont. Soc. Mem. 28: $1-41$.

Feldmann RM, Vega FJ, Applegate SP, Bishop GA. 1998. Early Cretaceous arthropods from the Tlayúa Formation at Tepexi de Rodríguez, Puebla, México. Jour. Paleo. 72: 79-90.

Förster R. 1969. Epökie, Entökie, Parasitismus und Regeneration bei fossilen Dekapoden. Mitt. Bayer. Staatssamml. Paläont. hist. Geol. 9: 45-59.

Fraaije RHB. 2003. The oldest in situ hermit crab from the Lower Cretaceous of Speeton, UK. Palaeontology 46: 53 57.

Fritsch A, Kafka J. 1887. Die Crustaceen der Böhmischen Kreideformation. Praha: Selbstverlag. 
Glaessner MF, 1969. Decapoda.In* Moore RC. (ed.). Treatise on Invertebrate Paleontology, Part $R$, Arthropoda 4(2): R400-R533. Boulder: Geological Society of America/ Lawrence: University of Kansas :Press.

Houša V. 1963. Parasites of Tithonian decapod Crustacea (Štramberk, Moravia). Sbornik Ústr. Úst. Geol. 38:101116.

Manton SM. 1977. The Arthropoda. Oxford: Clarendon Press.

Müller P. 1984. Decapod Crustacea of the Badenian. Geol. Hung, Ser. Palaeont. 42: 1-317.

Müller P, Collins JSH. 1991. Late Eocene coral-associated decapods (Crustacea) from Hungary. Contr. Tert. Quatern. Geol. 28: 47-92.

Overstreet, RM. 1983. Metazoan symbionts of crustaceans. In: Provenzano Jr AJ. (ed.). Pathobiology 6, The biology of Crustacea: 156-250. New York: Academic Press.

Ross DM. 1983. Symbiotic relations. In* Vernberg FJ, Vernberg WB. (eds). Behavior and ecology, 7, The biology of Crustacea: 163-212. New York: Academic Press.

Schäfer W. 1972. Ecology and palaeoecology of marine environments (edited by G. Y, Craig). Chicago: University of Chicago Press.

Schweitzer CE, Feldmann RM. 2000. New fossil portunids from Washington, USA, and Argentina, and a re-evaluation of generic and family relationships within the Portunoidea Rafinesque, 1815 (Decapoda: Brachyura), Jour. Paleo. 74: 636-653.

Sehweitzer CE, Feldmann RM. 2001. Differentiation of the fossil Hexapodidae Miers, 1886 (Decapoda: Brachyura) from similar forms. Jour. Paleo. 75: 330-345.

Schweitzer CE, Scott-Smith PR, Ng PKL. 2002. New occurrences of fossil decapod crustaceans (Thalassinidea, Brachyura) from late Pleistocene deposits of Guam, United States Territory. Bull. Mizunami Fossil Mus. 29: 25-49.

Schweitzer Hopkins CE, Feldmann RM. 1997. Sexual dimorphism in fossil and extant species of Callianopsis de Saint Laurent. Jour. Crust. Biol. 17: 236-252.

Straelen V van. 1928 Contribution à l'étude des isopods méso- et cénozoiques. Mém. Acad. r. Belg., Cl. Sci. (2)9: 1-66.

Taylor PD. 1994 Evolutionary palaeoecology of symbioses between bryozoans and hermit crabs. Hist. Biol. 9: 157205.

Tshudy DM, Feldmann RM. 1988. Macruran decapods, and their epibionts, from the López de Bertodano Formation (Upper Cretaceous), Seymour Island, Antarctica. In: Feldmann RM, Woodburne MO. (eds). Geology and Paleontology of Seymour Island, Antaretic Peninsula. Mem. Geol. Soc. Amer. 169: 291-301.

Tshudy DM, Feldmann RM, Ward PD. 1989. Cephalopods: biasing agents in the preservation of lobsters. Jour. Paleo. 63: 621-626.

Zullo VA, Chivers DD. 1969. Pleistocene symbiosis: Pinnotherid crabs in pelecypods from Cape Blanco, Oregon. Veliger 12: 72-73, pl. 5 .

Received: 12 March 2003 